\title{
Cytokine Production in Mononuclear Cells of Human Milk Studied at the Single-Cell Level
}

\author{
U. SKANSÉN-SAPHIR, A. LINDFORS, AND U. ANDERSSON
}

Department of Immunology: Stockholm Lniversity: 10691 Stockholm /L.S.S. L.A. J: Department of Pediatrics, Danderyd Hospital, Danderyd /A.L.J: and Department of Pediatrics. St. Goran's Hospital. Stockholm /U.S.-S., U.A./. Swe'den

\begin{abstract}
In this study, we demonstrate that mononuclear cells of human milk have a potential for production of many different cytokines. We applied a technique for cytokine detection at the single-cell level using cytokine specific MAb and immunofluorescence. The characteristic staining pattern obtained represents intracellular cytokine production, which allows for the assessment of the cellular origin of production. Milk mononuclear cells were mitogenstimulated in vitro and cultured for $4 \mathrm{~h}$ and then stained for 13 cytokines. Lipopolysaccharide stimulation induced extensive production of the following monokines: IL-1 $\alpha$, IL-1 $\beta$, IL-1 ra, IL-6, IL-8, and tumor necrosis factor- $\alpha$. IL10 and granulocyte-macrophage colony-stimulating factor were smaller products, although detectable in most samples. The abundant monokine production correlated with the high number of macrophages in milk. Spontaneous monokine production in unstimulated cells could be detected in six out of 11 samples. The highest incidence was evident for IL-8. No spontaneous lymphokine production was detected. Considering the low proportion of lymphocytes, stimulation with phorbol myristate acetate in combination with ionomycin resulted in considerable production of the following lymphokines: IL-2, IL-3, IL-4, IL-10, interferon- $\gamma$, tumor necrosis factor- $\alpha$. Macrophages contributed to the high production of tumor necrosis factor- $\alpha$ and GM-CSF. IL-5 synthesis was detectable in only one sample. This work reveals that human milk mononuclear cells are potent producers of cytokines when mitogen stimulated in vitro. The in vivo implications of these findings remain to be investigated further. (Pediatr Res 34: 213216, 1993)
\end{abstract}

\section{Abbreviations}

BSS, balanced salt solution

GM-CSF, granulocyte-macrophage colony-stimulating factor

IFN, interferon

LPS, lipopolysaccharide

MMNC, milk mononuclear cell

PBMNC, peripheral blood mononuclear cell

PMA, phorbol-12 myristate 13-acetate

TNF, tumor necrosis factor

Breast feeding provides well-balanced nutrition combined with growth factors and immunologic protection. The anti-microbial

Received December 15, 1992: accepted March 23, 1993.

Correspondence and reprint requests: Ulrika Skansen-Saphir. Department of Immunology. Stockholm University, 10691 Stockholm, Sweden.

Supported by grants from Samariten Foundation and Sven Jerring Foundation. influence of breast milk mediated by secretory $\operatorname{IgA}$ and other humoral factors is well established (1).

Numerous viable cells are transferred to the child (2). The macrophages and lymphocytes, constituting 75 to $95 \%$ and 5 to $25 \%$, respectively, of the mononuclear cells in breast milk, have been shown to be immunocompetent, exhibiting diverse biologic activities $(3,4)$. Moreover, it has been demonstrated that the aqueous phase of the human milk contains soluble factors with immunoregulatory potential $(5-8)$. It has been suggested that certain of these effects are mediated by cytokines.

IL-1 (9-11), IL-2 (11), IL-6 (12), and TNF- $\alpha$ (13) have previously been detected in the aqueous phase. Most of these studies have applied different bioassays for cytokine detection. The shortcomings of such assays concern specificity and sensitivity and an inability to assess the site of production. This study was initiated to clarify possible mechanisms whereby breast-milk cells may exert immunoregulatory effects.

We have developed a method for detection of cytokines in individual cells using cytokine-specific MAb and indirect immunofluorescence (14). The specific staining pattern obtained through this procedure represents production within the cells as opposed to uptake of externally produced cytokines (15). We have applied this method to study the potential for production of 13 different cytokines in mononuclear cells from human breast milk. Maximal polyclonal $T$ cell activation has been induced by the direct protein kinase $\mathrm{C}$ activator PMA in combination with a calcium ionophore, ionomycin (16). Escherichia coli-derived endotoxin, LPS, which exclusively activates the macrophage population in the mononuclear cell fraction, has been used in parallel cultures to study the potential for monokine production.

\section{MATERIALS AND METHODS}

Collection of milk. Milk was collected (semiaseptically by lowpressure breast pump) from 11 healthy women 3 to 5 days after full-term delivery. Informed consent was obtained from volunteers. The milk was kept at room temperature and processed within $2 \mathrm{~h}$ of collection.

Preparation of $M M N C$. Applying a modification of the technique of Saito (12), the whole milk was centrifuged at $3000 \times g$ for $30 \mathrm{~min}$. The fat layer and whey were removed. Cells were resuspended in BSS. Mononuclear cells were obtained by centrifugation on a density gradient (Lymphoprep; Nycomed AS, Oslo, Norway). To detect possible spontaneous cytokine production, a portion of the cells was removed for immediate staining without prior culturing and mitogen stimulation (see below). These cells were stained for IL- $1 \alpha$, IL-1 $\beta$, IL-1 ra, IL-2, IL-5, IL6. IL-8, IL-10, TNF- $\alpha$, GM-CSF, and IFN- $\gamma$.

Frozen PBMNC, which previously were isolated from healthy blood donors by centrifugation on a density gradient (Lymphoprep), were used as a control of culturing and staining conditions.

Cell culture and cytokine induction. The rest of the cells were cultured $\left(1 \times 10^{6}\right.$ cells $\left./ \mathrm{mL}\right)$ at $37^{\circ} \mathrm{C}$ for $4 \mathrm{~h}$ in RPMI-1640 
medium (Flow Laboratories, Irvine, UK) supplemented with endotoxin-free $5 \%$ heat-inactivated human $\mathrm{AB}$ serum and 2 $\mathrm{mmol} / \mathrm{L} \mathrm{L}$-glutamine in pyrogene-free cell culture polystyrene wells (Costar, Cambridge, MA).

Mitogen activation. The cells were stimulated either with 0.5 $\mu \mathrm{mol} / \mathrm{L}$ ionomycin (ATC 31005, Calbiochem, La Jolla, CA) in combination with $1 \mathrm{ng} / \mathrm{mL}$ PMA (Sigma Chemical Co., St. Louis, MO) for induction of IL-2, IL-3, IL-4, IL-5, IL-10, IFN$\gamma$, TNF- $\alpha$, and GM-CSF or with LPS from $E$. coli serotype 0128:B12 (Sigma) at $100 \mathrm{ng} / \mathrm{mL}$ for induction of IL-1 $\alpha, \mathrm{IL}-1 \beta$, IL-I ra, IL-6, IL-8, IL-10, TNF- $\alpha$, and GM-CSF.

Cytokine-specific antibodies. The following cytokine-detecting $\mathrm{MAb}$ were used for indirect immunofluorescence staining: IL-2 (17.H.12), IL-3 (3.G.11), IL-4 (25.D.2), IL-5 (39.D.10), IL-10 (19.F.1), TNF- $\alpha$ (20.A.4), GM-CSF (5.A.2) (all rat IgG MAb from J. Abrams, DNAX, Palo Alto, CA) (17), IL-1 $\alpha$ and IL- $1 \beta$ (mouse IgG1 MAb, from Harry Towbin, Ciba Geigy Ltd., Basel, Switzerland) (18), IL-6 (Ig-61 mouse IgG1 MAb, from Toray Industries, Kamakura, Japan) (19), IL-1 ra (BDA-29, goat polyclonal IgG from British Bio-technology Products, UK), and IFN$\gamma$ (DIK-1 mouse IgG1 MAb from G. Andersson, Kabi Pharmacia, Stockholm, Sweden) (20). FITC-labeled second-step antisera with specificity against IgG subclasses of murine IgG or goat IgG, respectively, were purchased from Caltag Laboratories, South San Francisco, CA, and against rat IgGl from Vector Laboratories, Burlingame, CA). For direct staining. FITC-conjugated specific human IL-8 MAb (mouse IgG from Miroslav Ceska. Vienna, Austria) (21) was used.

Identification of monocytes was obtained through the staining with DAKO-MAC387 (IgG1, Dakopatts, Glostrup, Denmark) diluted 1:100, which reacts with a cytoplasmatic antigen expressed in monocytes and macrophages (Fig. 1D). This was done to calculate the proportion of monocytes to lymphocytes in individual milk samples.

Immunofluorescence staining of cytokines. Cultured cells were harvested after $4 \mathrm{~h}$ and washed in BSS (Gibco Ltd., Paisley, Scotland) supplemented with $0.01 \mathrm{~mol} / \mathrm{L} N$-2-hydroxyethylpiperazine- $\mathrm{N}^{\prime}$-2-ethanesulfonic acid buffer. Cells were transferred to adhesion slides (BioRad Laboratories, Munich, Germany) and were allowed to adhere electrostatically to the slides for $10 \mathrm{~min}$
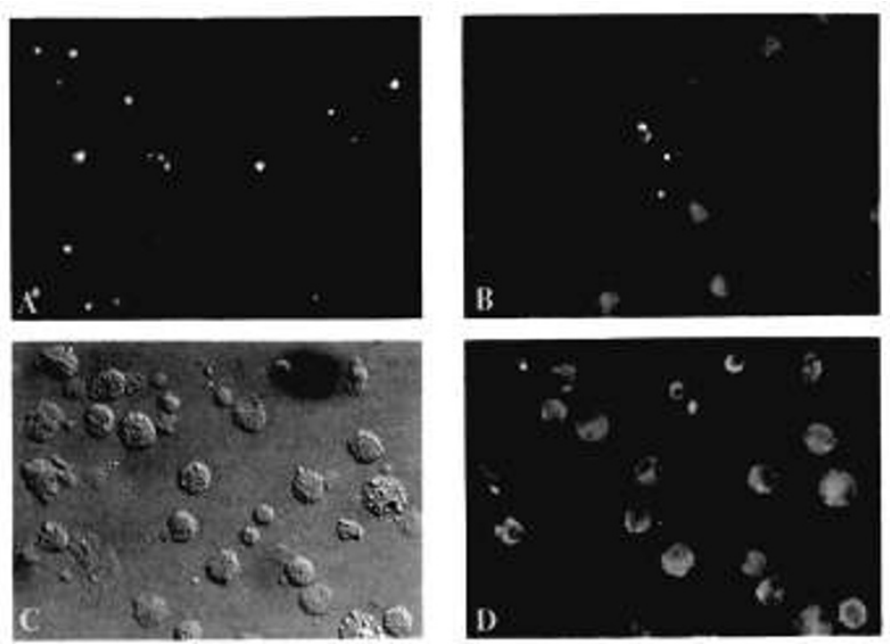

Fig. 1. $A$, Immunofluorescence staining of IL-6 in milk macrophages after LPS-stimulation for $4 \mathrm{~h}$. The local, perinuclear staining reflected accumulation in the Golgi organelle. $B$, Immunofluorescence staining of IL-2 in milk lymphocytes after PMA/ionomycin stimulation for 4 h. $C$, The morphology of MMNC as visualized by interference contrast light microscopy. The milk macrophages constituted a majority. They were large, vacuole-filled cells, whereas the lymphocytes were small, round, dense cells. $D$, Milk macrophages stained with MAC387 for phenotypic identification. The cells in this photograph correspond to the ones in Figure $1 C$. at room temperature. Excess cells were washed away, and the unbound surface area on the adhesive fields was blocked with $2 \% \mathrm{FCS}$ in BSS for $10 \mathrm{~min}$ at $37^{\circ} \mathrm{C}$.

The cells were fixed on each field with phosphate-buffered $4 \%$ paraformaldehyde at $\mathrm{pH} 7.4$ for $20 \mathrm{~min}$. After subsequent washes with BSS, the cells were permeabilized with BSS supplemented with $0.1 \%$ saponin (Riedel-de Haën AG, Seelze, Germany) to allow the intracellular entrance of the cytokine-specific MAb. Ten $\mu \mathrm{L}$ of the MAb, diluted to a final concentration of 1 to 5 $\mu \mathrm{g} / \mathrm{mL}$, were added and left to incubate for 20 to $30 \mathrm{~min}$ at $37^{\circ} \mathrm{C}$. The cells were then washed in BSS-saponin. Ten $\mu \mathrm{L}$ of the FITCcoupled second-step antibody were added for $30 \mathrm{~min}$ of exposure in darkness at room temperature. Dilution of all antibodies was performed in BSS-saponin with the addition of $10 \%$ human $A B$ serum. The FITC-labeled anti-mouse IgGl was used at a final concentration of $1: 300$ and FITC anti-rat IgG at 1:100.

After several washings with BSS-saponin, the final washings were performed with BSS exclusively. This prevented leakage of stained cytokines from the cells. The cells were left to dry on the slides. Buffered glycerol containing $2 \%$ diazobicyclo-octane was used at the mounting medium to reduce UV quenching.

Fluorescence microscopy. The slides were examined with a Reichert-Jung (Reichert Scientific Instruments, Buffalo, NY) fluorescence microscope equipped with a $200-\mathrm{W}$ mercury lamp.

Evaluation of results. The results are presented as the percentage of positively stained cells of total mononuclear cells counted (100 to 1000 cells, depending on cell yield). No consideration was made with respect to the proportion of monocytes to lymphocytes in milk.

\section{RESULTS}

Milk cells. We found that the total cell yield and proportion of individual cell types varied considerably between donors.

The predominant cell within the MMNC population was the macrophage constituting 75 to $95 \%$. Morphologically, the milk macrophage, a large, lipid-filled cell, differed from its counterpart in peripheral blood (Fig. $1 C$ ).

Cytokine staining patterns. As previously demonstrated for PBMNC, intracellularly produced cytokines, except IL- $l \alpha$ and IL- $\beta$, accumulated in MMNC in the Golgi organelle. This rendered the positively stained cells a characteristic pattern readily identified in the UV microscope (Fig. $1 A$ ), a pattern that was never seen after the addition of exogenous cytokines. As expected, the staining patterns for IL- $1 \alpha$ and IL- $1 \beta$ were diffused throughout the cytoplasm $(18,22)$. It is known that IL-l $\alpha$ and IL- $1 \beta$ are secreted through a different pathway than the classical endoplasmatic reticulum-Golgi route (23). We find it unlikely that any of the diffuse IL-1 staining occurred due to uptake of IL-1, because very little of this cytokine is secreted during the first $4 \mathrm{~h}$ of culture. The staining pattern for IL-1 ra was of the Golgi type, both in uncultured and cultured cells.

Cytokine production in unstimulated cells. In PBMNC (75 to $85 \%$ lymphocytes and 15 to $25 \%$ monocytes), the occurrence of spontaneous monokine and lymphokine production was consistently below 1:100 and 1:1000, respectively.

In unstimulated MMNC ( 5 to $25 \%$ lymphocytes and 75 to $95 \%$ macrophages), occasional production of IL- $1 \alpha$, IL-1 $\beta$, IL1 ra, IL-6, IL-8, and TNF- $\alpha$ was demonstrated, and in some instances the monokine-production was substantial (Fig. 2). The highest frequencies of producing cells were seen for IL-8. No spontaneous production was evident for lymphokines.

LPS-induced monokine production. In vitro stimulation of human milk with LPS (100 ng/mL) for $4 \mathrm{~h}$ resulted in a high incidence of monokine-producing cells (Fig. 3). Extensive production of IL- $1 \alpha$, IL- $1 \beta$, IL-ra, IL-6, IL-8, and TNF- $\alpha$ was demonstrated. The highest production was estimated for IL-8 ranging between 25 and $75 \%$. IL-10 and GM-CSF were in evidence in low quantities. The diversity in response profiles for monokine production between milk donors was striking. This 
$\%$ positive cells

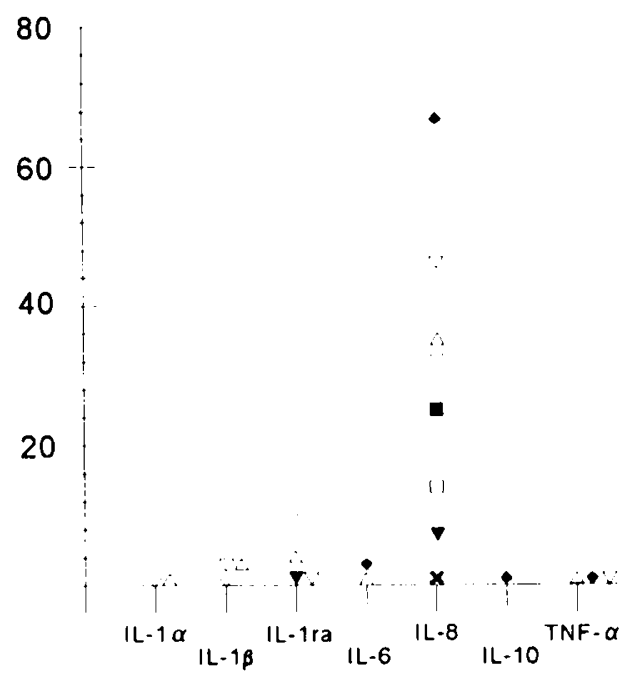

Fig. 2. Monokine production in unstimulated and uncultured MMNC. Samples without demonstrable synthesis are not listed. The figure indicates the frequency, in percentage of total cells counted, of cytokine-producing cells.

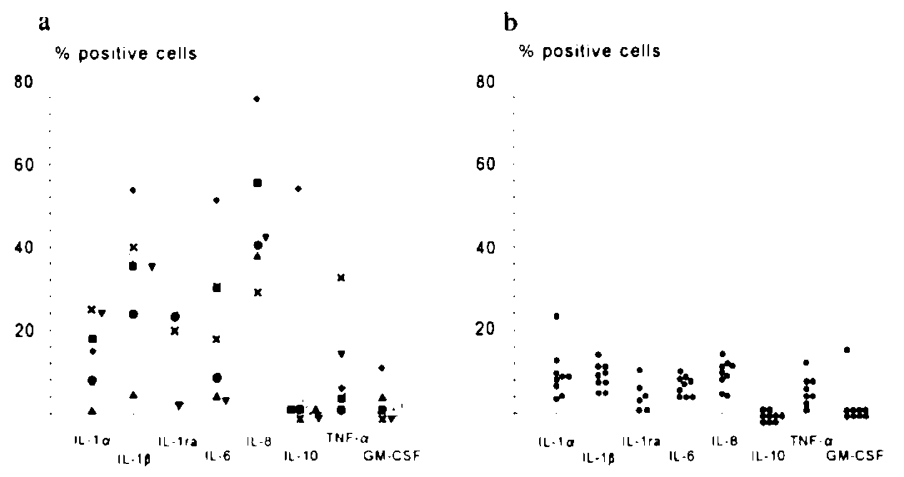

Fig. 3. Monokine production in MMNC $(a)$ and PBMNC $(b)$ after LPS stimulation.

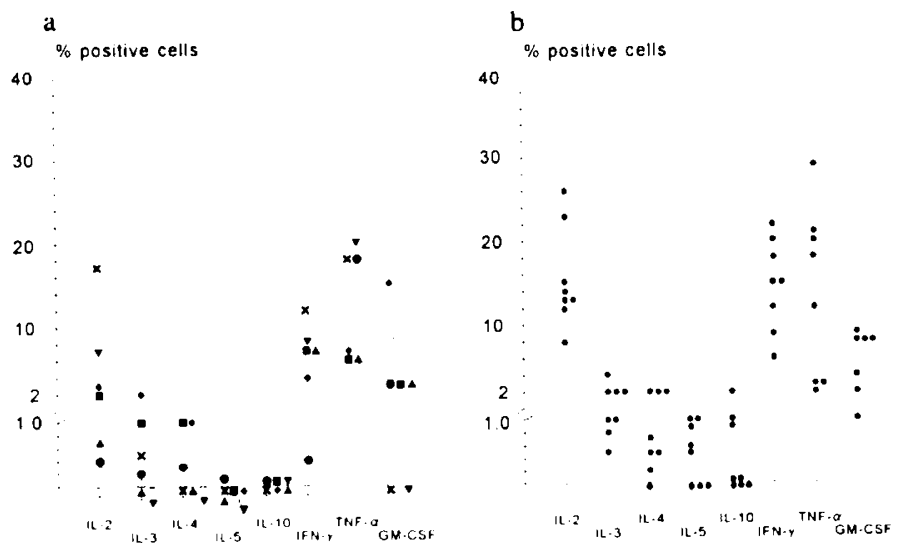

Fig. 4. Lymphokine production in MMNC $(a)$ and PBMNC $(b)$ after PMA/ionomycin stimulation.

differed from the relative conformity in response profiles obtained for PBMNC.

Lymphokine production induced by PMA in combination with ionomycin. After stimulation with PMA and ionomycin for $4 \mathrm{~h}$, lymphokine production reached high levels, considering the low numbers of lymphocytes present in human milk (Fig. 4). The most abundant lymphokines produced were IL- 2 and IFN- $\gamma$. The producing lymphocytes were small, round, dense cells, mor- phologically resembling lymphocytes in peripheral blood (Fig. $1 B)$. IL-5 production was detectable in only one of the milk samples. IL-4 and IL-10 were infrequent products, although certain samples exhibited up to $1 \%$ producing cells. Half of the donors showed production of IL-3 ranging from 0.2 to $3 \%$ of total cells. Macrophages contributed to the high levels of TNF- $\alpha$ and GM-CSF production.

\section{DISCUSSION}

The results of this study revealed a capacity of human breast MMNC to produce all of the studied 13 cytokines ex vivo. The biologic consequences in vivo for the recipient infant remain to be clarified. In particular, there is a need to understand what kind of stimuli may activate the milk cells in the gastrointestinal tract of the infant and for how long and at what localization the milk cells will stay viable in the recipient. It has been shown that human milk leucocytes, enterally administered to baboons, adhered to the mucosa and remained there for up to $60 \mathrm{~h}$ (24).

If we make the assumption that the abundant number of cells present in human breast milk do indeed play an active part after being exported, we can speculate about the biologic consequences based on the findings in this study. The significant production of monokines after exposure to LPS, present in all gram-negative bacteria, could increase the capacity of the infant to withstand microbial challenge. Previous reports about the presence of monokines such as IL-1 (9-11), IL-6 (12), and TNF- $\alpha$ (13) in the aqueous phase of breast milk and the findings in our study of monokines in noncultured milk cells indicate that such protective mechanisms may exist. However, in this study, we cannot exclude that contaminating endotoxins might have induced the cytokine production ex vivo after the sampling. This factor may certainly also operate in the natural breast-feeding situation.

Viable milk $T$ cells could have the potential to react and be activated by the exposure to the semiallogeneic cells present in the gastrointestinal tract of the infant. It has been indicated in one study that cell-mediated immunity may be transferred in human neonates from the mother via breast feeding (25). Concerning the potential for synthesis of lymphokines in milk $T$ lymphocytes, it may also contribute to the anti-microbial defense by influencing $\mathrm{B}$ lymphocyte and macrophage differentiation and activation. The fact that a high proportion of the milk lymphocytes were conducive to lymphokine production may be explained by the presence of a dominance of phenotypical memory $T$ cells in the $T$ cell population (26).

In summary, we found that breast milk cells have a potential for cytokine production, the in vivo relevance of which needs to be studied further.

Acknowledgments. The authors thank Caroline Ekberg and Lena Radler for excellent technical assistance, Gunilla Tillinger for her secretarial and editorial skill, and Dr. Jan-Inge Henter and Dr. Erik Enocksson for reviewing the manuscript.

\section{REFERENCES}

1. Howie PW, Forsyth JS, Ogston SA, Clark A, du V Florey C 1990 Protective effect of breast-feeding against infection. Br Med J 300:11-16

2. Crago SS. Princ SJ. Pretlow TG, McGhee JR, Mestecky J 1979 Human colostral cells. Clin Exp Immunol 38:585-597

3. Parmely MJ, Beer AE, Billingham RE 1976 In vitro studies on the T-lymphocyte population of human milk. J Exp Med 144:358-370

4. Speer CHP. Gahr M. Pabst MJ 1986 Phagocytosis-associated oxidative metabolism in human milk macrophages. Acta Paediatr Scand 75:444-451

5. Juto $P 1985$ Human milk stimulates $B$ cell function. Arch Dis Child 60 : 610-613

6. Pittard III WB. Bill K 1979 Immunoregulation by breastmilk cells. Cell Immunol 42:437-441

7. Mincheva-Nilsson L. Hammarström ML. Juto P. Hammarström S 1990 Human milk contains proteins that stimulate and suppress $T$ lymphocyte proliferation. Clin Exp Immunol 79:463-469

8. Hooton JWL, Pabst HF. Spady DW. Paetkau V 1991 Human colostrum contains an activity that inhibits the production of IL-2. Clin Exp Immunol $86: 520-524$ 
9. Söder O 1987 Isolation of interleukin-1 from human milk. Int Archs Allergy Appl Immunol 83:19-23

10. Munoz C, Endres S, van der Meer J, Schlesinger L. Arevalo M. Dinarello C 1990 Interleukin $1 \beta$ in human colostrum. Res Immunol 141:505-513

11. Nicolova E, Staykova M, Raicheva D, Karadjova M, Neronov A, Ivanov I. Goranov I 1990 Interleukin production by human colostral cells after in vitro mitogen stimulation. Am J Reprod Immunol 23:104-106

12. Saito S, Maruyama M, Kato Y. Moriyama I. Ichijo M 1991 Detection of IL-6 in human milk and its involvement in IgA production. J Reprod Immunol 20:267-276

13. Rudloff HE. Schmalstieg Jr, FC. Mushtaha AA. Palkowetz KH, Liu SK. Goldman AS 1992 Tumor necrosis factor- $\alpha$ in human milk. Pediatr Res 31:29-33

14. Sander B, Andersson J, Andersson U 1991 Assessment of cytokines by im. munofluorescence and the paraformaldehyde-saponin procedure. Immunol Rev 119:65-93

15. Sandvig S, Laskay T, Andersson J, De Ley M, Andersson U 1987 Gammainterferon is produced by $\mathrm{CD}^{+}$and $\mathrm{CD}^{-}$lymphocytes. Immunol $\mathrm{Rev}$ 97:51-65

16. Andersson U, Andersson J. Lindfors A, Wagner K. Möller G. Heusser CH 1990 Simultaneous production of interleukin 2 . interleukin 4 and interferon$\gamma$ by activated human blood lymphocytes. Eur J Immunol 20:1591-1596

17. Abrams JS, Roncarolo M-G, Yssel H, Andersson U, Gleich GJ. Silver JE 1992 Strategies of anti-cytokine monoclonal antibody development: immunoassay of IL-10 and IL-5 in clinical samples. Immunol Rev 127:5-24

18. Andersson J. Björk L, Dinarello C. Towbin H. Andersson U 1992 Lipopoly- saccharide induces human interleukin- 1 receptor antagonist and interleukin1 production in the same cell. Eur Immunol 22:2617-2623

19. Ida N. Sakurai S, Hosaka T, Hosoi K. Kunimoto T, Shimazu T, Maruyama T. Matsuura Y. Kohase M 1989 Establishment of strongly neutralizing monoclonal antibody to human interleukin-6 and its epitope analysis. Biochem Biophys Res Commun 165:728

20. Andersson G, Ekre H-P, Alm G, Perlmann P 1989 Monoclonal antibody twosite ELISA for human IFN-gamma. J Immunol Methods 125:89-96

21. Martich GD. Danner RL, Ceska M. Suffredini AF 1991 Detection of interleukin 8 and tumor necrosis factor in normal humans after intravenous endotoxin. J Exp Med 173:1021-1024

22. Conlon PJ, Grabstein KH. Alpert A. Prickett KS. Hopp TP. Gillis S 1987 Localization of human mononuclear cell interleukin 1. J Immunol 139:98102

23. Bakouche O, Brown DC, Lachmann LB 1987 Subcellular localization of human monocyte interleukin !: evidence for an inactive precursor molecule and a possible mechanism for IL-1 release. J Immunol 138:4249-4255

24. Jain L. Vidyasagar D. Xanthou M. Ghai V. Shimada S, Blend M 1989 In vivo distribution of human milk leucocytes after ingestion by newborn baboons. Arch Dis Child 64:930-933

25. Ogra SS. Weintraub D. Ogra PL 1977 Immunologic aspects of human colostrum and milk. Fate and absorption of cellular and soluble components in the gastrointestinal tract of the newborn. J Immunol 119:245-248

26. Bertotto A. Gerli R. Fabietti G, Crupi S. Arcangeli C. Scalise F. Vaccaro R 1990 Human breastmilk T lymphocytes display the pheno-type and functional characteristics of memory T cells. Eur J Immunol 20:1877-1880 